\title{
Land Suitability Zoning for Ecotourism Planning and Development of Dikgatlhong Dam, Botswana
}

\author{
Ante ŠiljegA , Branko Cavrić ${ }^{\text {, Silvija Šiljeg }}$, Ivan MarićA , Mirko BaradaA* \\ Received: February 19, 2019 | Revised: April 22, 2019 | Accepted: April 25, 2019 \\ DOI: 10.5937/gp23-20633
}

\begin{abstract}
The main objective of this paper was to discuss applications of GIS based multi-criteria decision analysis (GIS MCDA) and Analytical Hierarchy Process (AHP). These two techniques were applied in order to assist preparation of the Tourism Management Plan, depicting the most suitable zones for ecotourism development in Dikgathlong Dam Lease Area (DDLA) as one of the largest resources of potable water in Botswana. The MCDA was based on geo-morphometric, hydrologic, landscape and community indicators and criteria which emanated from expert's opinions, intensive field survey and literature review. In addition the AHP has helped to calculate individual criteria weights and to point the degree of suitability zones classified as highly suitable, moderately suitable, marginally suitable and not suitable for ecotourism. After performing both processes and establishing broad management zones it has been found that the Sustainable Development Scenario is the most appropriate option as the future ecotourism development proposal. This research provides new methodology that can be incorporated into future tourism policies and management strategies.
\end{abstract}

Keywords: GIS, multi-criteria decision analysis (MCDA), analytical hierarchy process (AHP), ecotourism, land suitability zoning.

\section{Introduction}

The tourism sector is one of important drivers of Botswana's economic growth and over the years has contributed significantly to the country's economic output (accounting for almost 12\% of GDP) (Saarinen et al., 2012; Statistics Botswana, 2015, GISPlan, BTO, 2016; 2017). The challenge however, is that even though Botswana is endowed with a wide range of tourism assets, and referent institutions has brought numerous tourism acts and strategies, which provide the basis for developing a much more diversified tourism product for the country, it is not all yet developed to fullest potential (Mbaiwa, 2005; Kaynak \& Marandu, 2006; Basupi et al., 2017). In this way, niche tourism products and markets (such as Dam tourism) can be created and propagated in Botswana.
Ecotourism is the most recently used term for a sustainable form of tourism targeting preserved areas which need environmental conservation, visitors education, cultural preservation and experience, and economic benefits for local community (Cobbinah, 2016; Gigović et al., 2016; The International Ecotourism Society [TIES], 2015). It emerged in the 1990's as an alternative form in order to neutralize the disadvantages of conventional (mass) tourism, with respect to sustainable development (Bunruamkaew \& Murayam, 2011). From socio-economic standpoint, ecotourism delivers a variety of economic benefits (Whelan, 1991; Cobbinah, 2016). Ideally, ecotourism should take care of conservation of biological, hydrological and cultural

\footnotetext{
A University of Zadar, Department of Geography; asiljeg@unizd.hr, ssiljeg@unizd.hr, imaric1@unizd.hr, mbarada@unizd.hr

B University of Botswana, Faculty od Engineering and Technology, Department of Architecture and Planning; cavricb56@gmail.com

* Corresponding author: Mirko Barada; e-mail: mbarada@unizd.hr
} 
diversities (Ryngnga, 2008; Cobbinah, 2016; Gigović et al., 2016).

GIS and remote sensing tools are widely used for identifying location suitability and resource inventories according to environmental, socio-economic and spatial planning concerns (Jankowski \& Richard, 1994; Malczewski, 2006, Charabi \& Gastli, 2011; Gigović et al., 2016). GIS suitability mapping involves usage of a different data sources where weights are assigned to determine the importance of particular criteria (Janke, 2010; Bunruamkaew \& Murayam, 2011; Al-Yahyai et al., 2012). In recent years, multicriteria decision analysis (MCDA) or multicriteria decision making approach (MCDMA) is widely exploited by many experts in order to holistically evaluate the suitability of particular land area for different purposes, e.g. flooding prevention (Fernández \& Lutz, 2010), wildfire risk estimation (Kant Sharma et al., 2012), agricultural management (Mendas \& Delali, 2012) or energy generation (Abudeif et al., 2015). A few efforts were done to analyze ecotourism potentials as well (Bunruamkaew \& Murayam, 2011; Koschke et al., 2012; Gigović et al., 2016; Jeong et al., 2016; Fang, 2017; Çetinkaya et al., 2018).

One of the most widely used MCDA weight estimation and criteria correlation technique is the An- alytical Hierarchy Process (AHP) (Mardani et al., 2015). This method provides a structural basis for quantifying the comparison of decision elements and criteria in a pair wise matrix (Saaty, 1980). Typically, the priority of each factor involved in the AHP analysis is determined based principally on the expert's opinions or information from various literature sources (Saaty, 2008; Alexander, 2012). This method has proven as beneficial decision-making tool for future planning of tourism facilities, ecotourism resource utilization and sustainable development (Zhang \& Yang, 2009; Bunruamkaew \& Murayam, 2011; Mohd \& Ujang, 2016).

By using the aforementioned practices the main goal of this research was to identify and categorize locations suitable for ecotourism development in the wider Dikgatlhong Dam Lease Area (DDLA) in Botswana, based on the following:

1. Finding suitable criteria to be used in the analysis

2. Assigning criteria priority, weight and class weight (rating) to the parameters involve

3. Production of land suitability maps for ecotourism development potential

4. Zoning of ecotourism potential areas (Broad Management Zoning - BMZ).

\section{Study area}

Dikgatlhong Dam is situated in the north-eastern part of Botswana about five kilometres upstream of the Botswana-Zimbabwe border at the confluence of Shahi and Tati River, and in close proximity to villages of Robelela to the South, Matopi to the North and Patayamatebele to the NW (Figure 1). The DDLA covers an area of $13,124.64$ ha, while the Dam itself is a zoned earth fill structure, 41 metres high and 4.5 kilometres in length. Dikgatlhong Dam, as the largest dam in the country, has a total capacity of 400 million $\mathrm{m}^{3}$.

Border of the lease area was agreed by respecting several criteria, among which the most relevant were

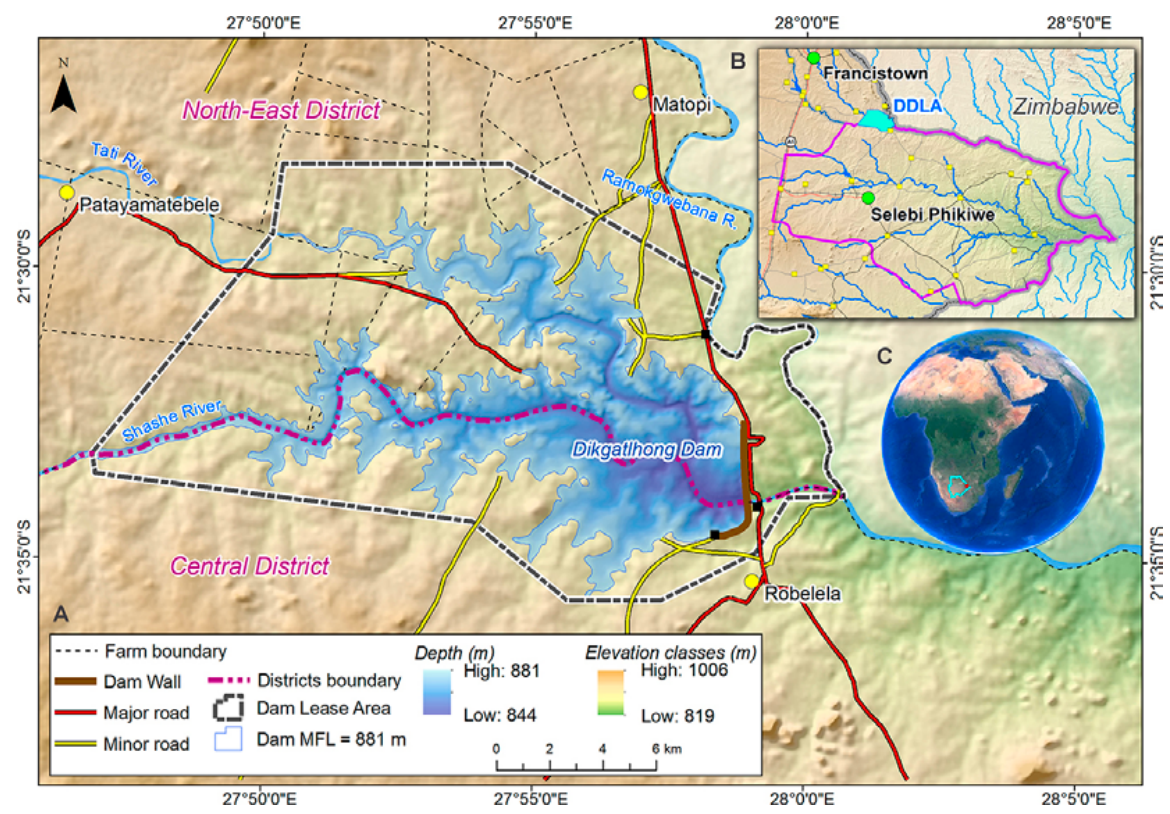

Figure 1. Study area 
tribal regulation, govermental regulation, as well as general consensus with local community (GISPlan, BTO, 2016; 2017). As a result, the present border of the DDLA represents a compromise, still ongoing (Figure $1, \mathrm{~A})$. The land tenure in the DDLA is all tribal land. However, Water Utilities Corporation (WUC) has leased a large area so far and there is a recent in- tention to make consensus with Botswana Tourism Organization (BTO) who will then be in a position to lease concession areas to prospective tourism operators. The Dam falls within the SPEDU (The Selebi Phikwe Diversification Unit Company) region, dedicated for diversified economic development (Figure 1, B) (GISPlan, BTO, 2016; 2017).

\section{Materials and methods}

\section{Data Sources}

During the planning process the five-step data collection approach encountered for the following: (i.) primary and secondary data collection; (ii.) development of GIS mapping models based on concepts, spatial/environmental logics and mathematical calculus; (iii.) GIS analysis and visualisation of criteria identified; (iv.) interpretation of analytical data and aerial zoning according to suitability; (v.) application of the results and stakeholders involvement.

The primary data from the field survey were collected through administration of interview questionnaires to the public. This helped to merge outcomes from field survey, literature findings, historical, sta- tistical, GPS and drone record with GIS and environmental planning expert datasets. Additionally, some open data sources were also utilised including Statistics Botswana, Regional Center for Mapping of Resources for Development (RCMRD), and Earth Explorer.

\section{Multi-Criteria Evaluation (MCE) and Analytical Hierarchy Process (AHP)}

After goals setting, the combined MCA and AHP methodology was performed in five major steps specifying the hierarchical structure, determining the relative important weights of the criteria and sub-criteria, assigning preferred weights of each alternative,

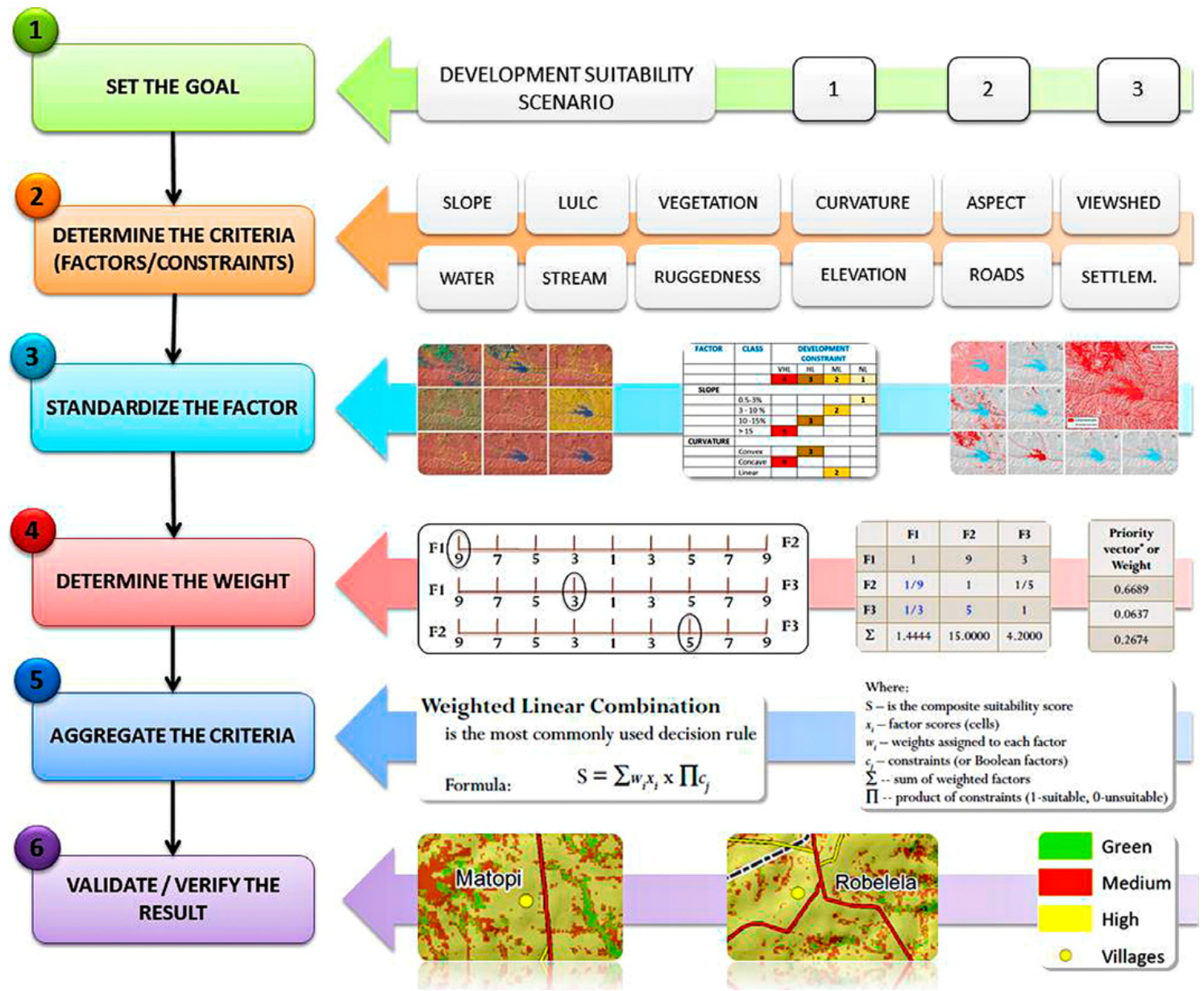

Figure 2. Phases of MCDA process (Source: GISPlan, BTO, 2017) 
determining the final score, and, finally, validating achieved results/model (Figure 2).

\section{Determination and Classification of Criteriae}

The following set of criteria as indicators of suitability within the land ecosystem of DDLA context were identified and analysed: geomorphometric (slope, aspect, ruggedness, land form, planar curvature), landscape (vegetation, land cover and land use), hydrology (rivers and lakes) and community features (settlement size and roads accessibility) (Table 1).

\section{Hydrology}

Drainage density of DDLA is a sign of amount of streams and tributaries, leading to a relatively rapid hydrologic response to rainfall events, or having a slow hydrologic response in a poorly drained basins (Curry \& Horn, 2009). In the context of future ecotourism development, the DDLA basin act as focus for potential ecotourism sites. Its surrounding tributaries and central water body are crucial for spatial organisation of tourism activities based on water carrying capacities.

Table 1. Criteriae used in the research

\begin{tabular}{|c|c|c|c|c|}
\hline Cluster & Factors & Unit & Source & Reference \\
\hline \multirow{2}{*}{ Landscape } & Land use/Land cover & class & $\begin{array}{l}\text { RCMRD (2010); } \\
\text { LANDSAT (2015) } \\
-30 \mathrm{~m}\end{array}$ & \multirow{2}{*}{$\begin{array}{l}\text { Bunruamkaw \& Murayam, 2011; Gigović et al., 2016; } \\
\text { Jeong et al., 2016; Fang, 2017; Çetinkaya et al., } 2018\end{array}$} \\
\hline & Vegetation & class & $\begin{array}{l}\text { LANDSAT (2015) } \\
\text { - } 30 \text { m; Terrain } \\
\text { mapping }\end{array}$ & \\
\hline \multirow{5}{*}{ Topography } & Slope & degree & \multirow{5}{*}{$\begin{array}{l}\text { Topographic map } \\
(1: 25.000) ; \\
\text { Terrain mapping }\end{array}$} & $\begin{array}{l}\text { Zingg, 1940; Lee \& Min, 2001; Saha et al., 2002; } \\
\text { Fernández \& Lutz, 2010; Jeong et al., 2016; Fang, } \\
\text { 2017; Çetinkaya et al., } 2018\end{array}$ \\
\hline & Planar curvature & type & & Ayalew et. al., 2004; Milevski, 2008 \\
\hline & Landform & type & & Blaszczynski, 1997 \\
\hline & Aspect & $\begin{array}{l}\text { side } \\
\text { orientation }\end{array}$ & & $\begin{array}{l}\text { Mitasova et al., 1996; } \\
\text { Kumar et al., 1997; Fang, 2017; Çetinkaya et al., } 2018\end{array}$ \\
\hline & Ruggedness & type & & Sappington et al., 2007; Hochstetter et al., 2008 \\
\hline Hydrology & Rivers and lakes & mask & $\begin{array}{l}\text { National Data } \\
\text { Infrastructure }\end{array}$ & $\begin{array}{l}\text { Mahdavi \& Niknejad, 2014; Gigović, 2016; Jeong et al., } \\
\text { Fang, 2017; Çetinkaya et al., } 2018\end{array}$ \\
\hline \multirow{2}{*}{ Community } & Settelment size & $\begin{array}{l}\text { population } \\
\text { size }\end{array}$ & Census 2001 & $\begin{array}{l}\text { Bunruamkaew \& Murayam, 2011; Jeong et al., 2016; } \\
\text { Fang, 2017; Çetinkaya et al., } 2018\end{array}$ \\
\hline & Road network & mask & $\begin{array}{l}\text { National Data } \\
\text { Infrastructure }\end{array}$ & $\begin{array}{l}\text { Gigović et al., 2011; Chandio \& Matori, 2011; Fang, } \\
\text { 2017; Çetinkaya et al., } 2018\end{array}$ \\
\hline
\end{tabular}

\section{Geomorphometric parameters}

Terrain mapping was performed because the Dikgatlhong Dam was not built at the time when official DSM topographic maps were produced. A digital rasterbased terrain model (DTM) of the DDLA was generated from contours after vectorization of topographic map (1:25.000). Elevation dataset was created using ANUDEM method as the most effective way for interpolating contours (Hutchinson, 1989). Suitable pixel size (spatial resolution) was set to $5 \mathrm{~m}$, according to the Complexity of terrain method (Hengel, 2006, Šiljeg et al., 2018). Five geomorphometric parameters were identified as relevant for the purpose of this research, since literature review showed that they were already used in similar analysis: slope (Zingg, 1940; Lee \& Min, 2001; Fernández \& Lutz, 2010; Saha et al., 2002), planar curvature (Schmidt, 2003; Šiljeg et al., 2018; Ayalew et al., 2008), aspect (Mitasova et al., 1996; Kumar et al., 1997), ruggedness (Lozić, 1995; Sappington et al., 2007; Hoechstetter et al., 2008) and landforms (Swanson et al., 1988).

\section{Landscape parameters}

Land Cover/Land Use (LCLU) - The DDLA land cover is dominated bylimited woodland facets, bush land, savannah, wooded and open grassland (Bunruamkaew \& Murayam, 2011; Gigović et al., 2016). According to Land Cover/Land Use (LCLU) map, generated from the RCMRD (2010) and the United States Geological Survey (USGS) - Earth Explorer (2015) data bases (Fuzzy overlay), there were seven distinctive LCLU classes in DDLA planning area. Each class is importance for balancing bio-diversity and human activities in tune with nature.

\section{Vegetation}

The DDLA vegetation classes are generated from the same data source by performing supervised classification of satellite images (USGS - Earth Explorer, 2015), as well as terrain mapping for model quality control. Similarly, to other important factors which could attract tourism and mitigate environment, different measures 
for further expansion of vegetation and related wildlife species are incorporated in criteria for generating suitability maps for the three planning scenarios (Bunruamkaew \& Murayam, 2011; Gigović et al., 2016).

\section{Community}

Settlement size

Settlement and population zones were excluded as potential ecotourism areas, due to fact that their existence is opposed to the main principles of sustainable tourism (Bunruamkaew \& Murayam, 2011). According to the Population Census (2011), the largest of all settlements surrounding the Dam is Mmadinare, with a total population of 11,672 . It is followed by Matsiloje (2,380), Tshokwe (1,070), Robelela (829) and Patayamatebele (349).

\section{Road network}

The accessibility of the ecotourism site is largely affected by current road network which needs upgrades and improvements in order to enables the development of DDLA tourist destination and brand (Chandio et al., 2014).

\section{Determination of Weight Values and Standardzation of Criteria}

After relevant criteria were studied and combined, the process of weight value estimation and standardization commenced. Two different approach were used in this regard: (i.) boolean mask (constraints) and (ii.) continuous surface method with analytical hierarchy process. Range of class values was from o (not suitable) to 1 (highly suitable), with only o and 1 in the case of Boolean approach, and with intermediate values in the case of continuous surfaces.

The AHP method was applied by using Microsoft Excel and ArcGIS to determine the relative importance of all selected factors. The total suitability score for each land unit (i.e. each raster map cell/pixel) was calculated applying linear combination of individual suitability scores for each criterion. For MCDA method, the assigned weights were summed up to 1 for each category/subcategory, and then each criterion in the last layer was grouped into 4-5 suitability classes with their appended scores ranging from o to 1 . The total suitability score for each criterion was accumulated in order to produce contextual maps for conservation, sustainable and intensive ecotourism development.

To ensure the credibility and relative results significance, the AHP has also provided mathematical judgement and determined inconsistency. According to references from literature (which point on ratios between 0.04-0.10), the attained Consistency Ratio Index (CRI) of 0.04, was acceptable for the DDLA suitability analysis and establishment of the four ( $\mathrm{S}_{1-}$

S4) development suitability classes:

- S1 Class: Minor or no suitability limitations (no development restrictions).

- S2 Class: Moderate limitation (moderate development)

- S3 Class: High suitability limitation (low development)

- S4 Class: Very high limitations (low or no development)

\section{Broad management zoning}

DDLA was delineated into broad management zones, with three alternatives presented for evaluation and consideration, where ad what kinds of land use zones/ activities shall be best located in the DDLA. These zones have been established to serve as management units, within which prospective tour operators/concessionaires shall (through open tenders) be granted rights to carry on prescribed or recommended tourism activities for each zone.

The zonation is based on the outcomes of previously described spatial and suitability analysis, which considered all aforementioned factors and parameters for ecotourism development inclusive of bio-physical characteristics, resources and site location, vis-a-vis the whole DDLA, and related tourism and recreational attractions/opportunities. The management zones, thus aim at classifying land development uses within zones according to the levels of sensitivity and suitability of each zone. Management zones are to a large extent aligned with the zoning requirements in terms of activity types (land and water based). It is envisaged that specific land use/tourism activities will be assigned to each zone, Based on the zone type it is believed that tourism activities and facilities presented in Table 2 would be in line with the tourism development vision for Dikgatlhong Dam eco-tourism areas. 


\section{Results and discussion}

\section{Site suitability analysis planning scenarios recommendations}

Conservation Development - Suitability Scenario I

This scenario was proposed in order to guide DDLA development zones with ecological and resource significance and thus important for their protection and conservation. In summary its aim is to support conservation of ecologically fragile transects which include riparian vegetation and flooding zones presented in Figure 3.

As can be gleaned from the map 3, there are four suitability classes assigned to this scenario. The largest is land protection area measuring $8,872.89$ ha or $43,49 \%$ of the total land mass. It is followed by water protection area (the dam) with the same regime of excluded development accounting for 7,474.14 ha or 36.64 $\%$. The low density type of development is allowed on $3,591.82$ ha or $17.60 \%$, thus placing the focus on conservation development and green urbanism types. The smallest land chunk belongs to fully restricted area on hilly sides with 462 ha or $2.27 \%$ respectively.
Zones of valuable natural vegetation and ecological sensitivity, which should be protected and conserved, while not being suitable for intensive development are more suited for recreational uses and wildlife habitats. Conservation efforts should therefore be focused on preservation/regeneration of natural vegetation cover, due to its role in wildlife support, water regime regulation, soil improvements and recreational opportunities.

\section{Sustainable Development - Suitability Scenario II}

The suitability analysis in this scenario has sought to establish the planning framework for controlled ecotourism developments where transition between nodevelopment and moderate developments should be highly visible (Figure 3). Based on principles of smart growth, resilient and sustainable development this scenario shows more flexibility. It has aimed to secure balance between "the design with nature" and concentrated developments based on use of sustainable building technologies and improved water and energy use.

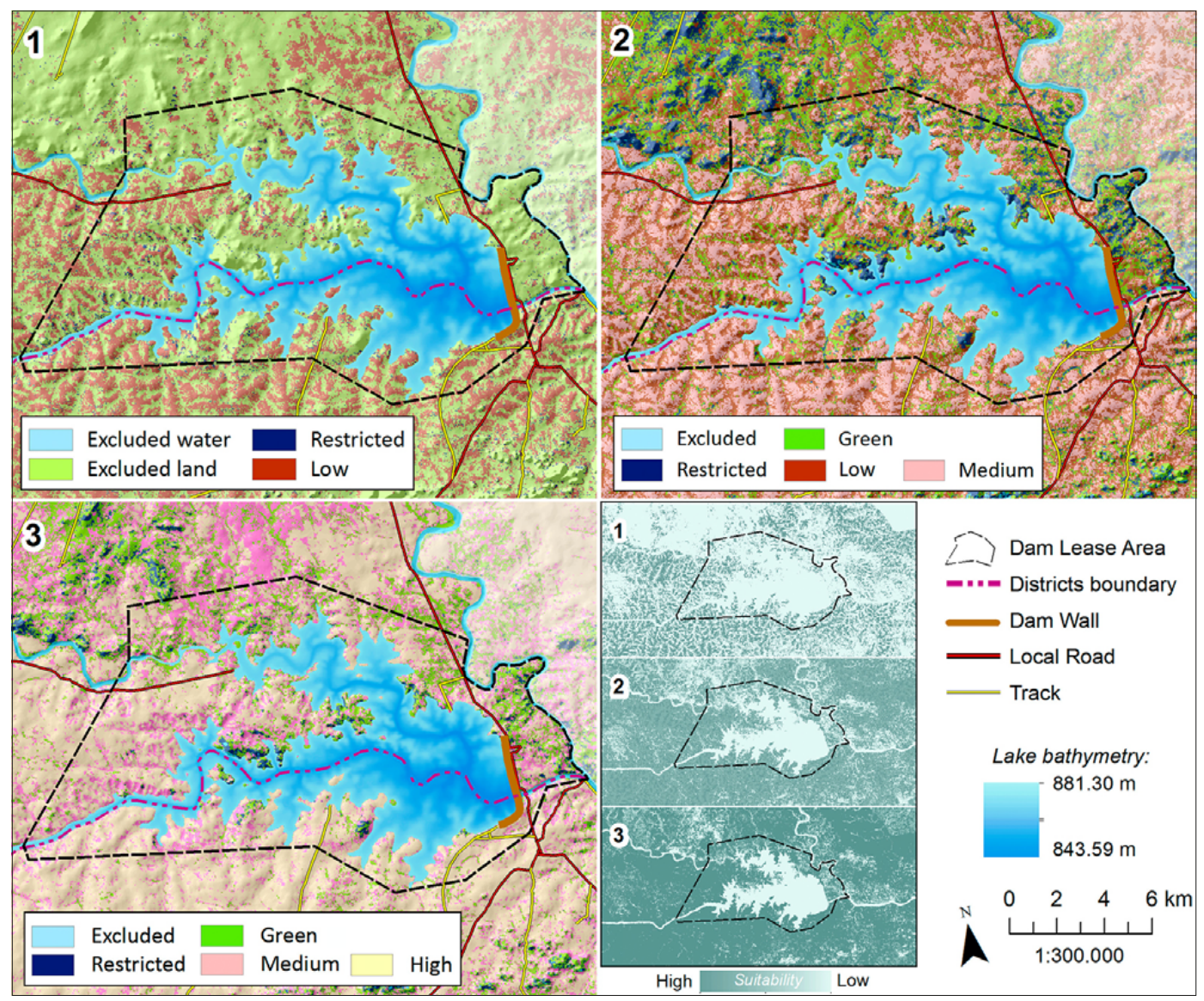

Figure 3. MCDA classification for 3 scenarios: 1) Conservation Development, 2) Sustainable Development and 3) Intensive Development 
The largest portion is still under protective regime which includes $7,501.06$ ha or $36.64 \%$ of the Dam water surface. Conservation sites cater for $1,504.89$ ha or $7.38 \%$ and they are all restricted for development. Different forms of green urbanism are permitted to take place at the bottom of hilly sides on 3,936.47 ha or $14.39 \%$ of land, under condition of application of adequate engineering and environmental protection techniques. Low density development is approved in an area of $4,515.21$ or $22.13 \%$, while the medium density development can be implemented on 3,945.04 ha or $19.34 \%$ of total DDLA.

\section{Intensive Development - Suitability Scenario III}

The third scenario is in favour of mass tourism and limits the extent of environmental protection and conservation. It allows introduction of more intensive forms of development spreading over larger portions of land. If not controlled, this type of development could compromise the basic function of the Dam as a water resource of national importance. Also, other valuable ecological elements (e.g. natural habitats, stream channels, quantity/quality of water, landforms), protected in previous two scenarios could be endangered and basic tourism attractions can fade away. This model opens the room for built-environment growth and intensive change of land use and land cover.

According to this planning framework one third of the area is still dominated by the Dam water body (Figure 3). Conservation area is highly limited absorb- ing only 363.70 ha or $1.78 \%$. On the other hand, this model captures more than 10,000 ha or $51.06 \%$ to be designated for different forms of medium and high density development. More sustainable development forms prescribed in Scenarios I and II are foreseen around hilly sides occupying 2,131.08 ha or $10.45 \%$.

\section{Recommended Planning Scenario - Proposed Tourism Management Plan}

Based on planning team work, public and clients inputs, and the MCDA results scrutiny, it was concluded that the best performance for ecotourism development may occur under Sustainable Development Scenario. Conservation Development Scenario doesn't leave much potential for economic development, while Intensive Development Scenario marginalizes some of the natural values of the area.

The proposed scenario depicts the sensitivity and suitability of the DLLA sites vis-a-vis the possible tourism activities/land uses, providing a wider range of tourism products that will appeal to various market segments. At the same time strives to strike a balance in terms of ensuring the sustainability of the ecosystems, biodiversity and acceptable change of DLLA carrying capacities without exceeding.

Eleven zones of sustainable development were established in this proposal and shown on Figure 4. Nature based activity use zone (land) covers an area of $5,265.77$ ha (dry land area and inundation area) or $32.60 \%$ of the total DDLA and nature based activ-

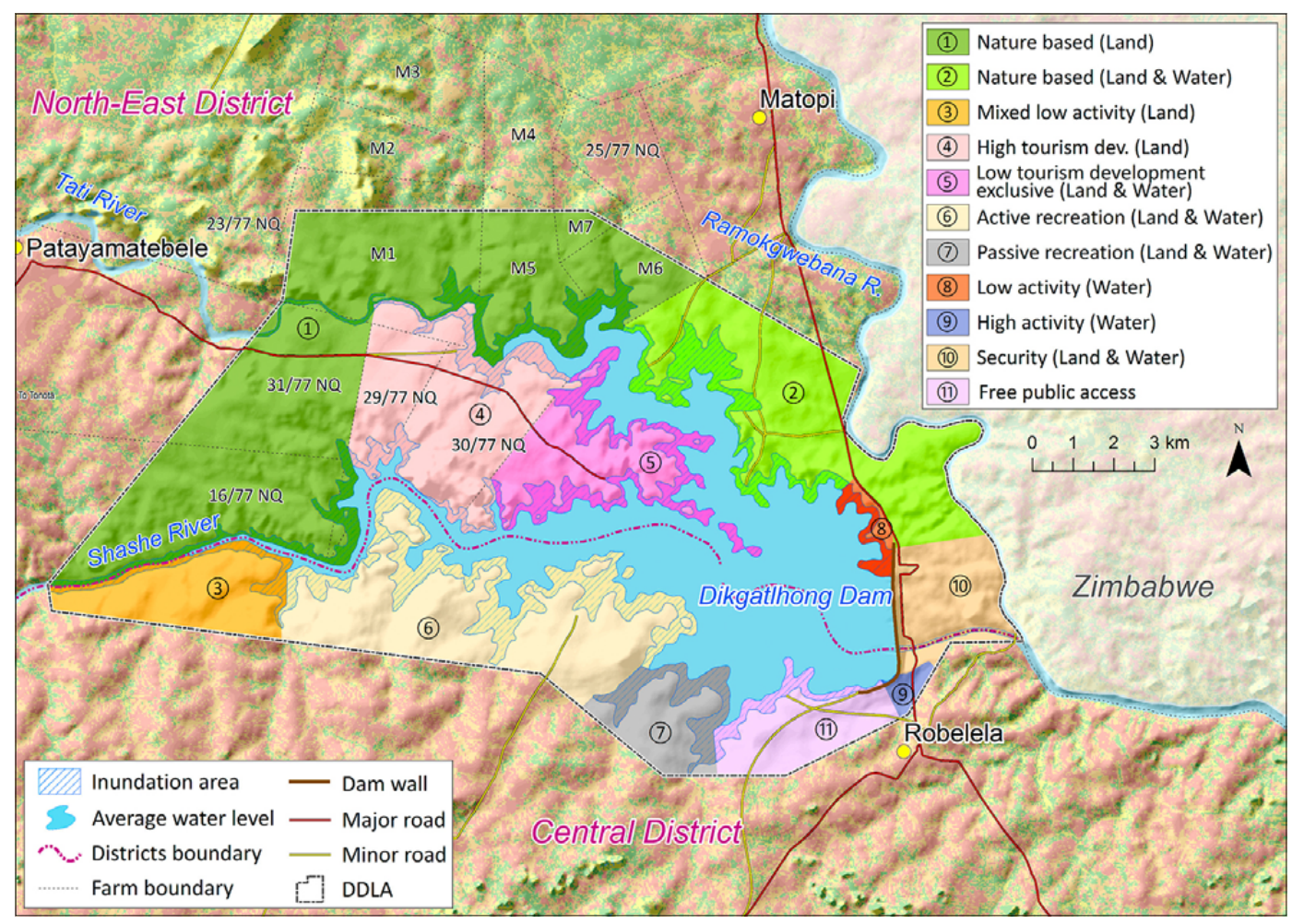

Figure 4. Sustainable development zoning proposal 
Table 2. Sustainable Development Zoning - Possible Land Uses and Activities

\begin{tabular}{|l|l|}
\hline Broad Zones & Possible Uses/Activities \\
\hline Nature Based Use Zone (Land) & $\begin{array}{l}\text { Game Park, Game viewing Drives, Guided walking Trails, Bird watching, Photographic } \\
\text { safaris }\end{array}$ \\
\hline Nature Based Use (Land \& Water) & Camping sites, walking Trails, Bird watching, sport fishing \\
\hline $\begin{array}{l}\text { Mixed Low Activity Use Zone } \\
\text { (Land) }\end{array}$ & Horse Riding, Curio/Coffee shops, Art Gallery \& Exhibitions \\
\hline $\begin{array}{l}\text { High Tourism Development Use } \\
\text { Zone (Land) }\end{array}$ & Lodges, Conference facilities, Hotel staff accommodation, corporate events \\
\hline $\begin{array}{l}\text { Low Tourism Development Use } \\
\text { Zone (Land) }\end{array}$ & $\begin{array}{l}\text { Holiday Homes/Apartments, Exclusive Lodge Resort, Corporate Retreat centre, Boat } \\
\text { cruises, sport fishing, Bird Watching }\end{array}$ \\
\hline $\begin{array}{l}\text { Active Recreational Use Zone } \\
\text { (Land \& Water) }\end{array}$ & $\begin{array}{l}\text { Theme/Amusement park, Roller Coaster, Jumping Castles, Hot air Balloon over the Dam, } \\
\text { Water slides, viewing Platforms, Vending stalls }\end{array}$ \\
\hline $\begin{array}{l}\text { Passive Recreational Use Zone } \\
\text { (Land \& Water) }\end{array}$ & $\begin{array}{l}\text { Picnic sites, viewing platforms, Bird watching, vending stalls, curio and craft shops, coffee } \\
\text { shops \& Restaurant, Braai Areas }\end{array}$ \\
\hline $\begin{array}{l}\text { Low Activity Use Zone (Water) } \\
\text { Aport fishing, Boat sailing, House Boat cruising, canoeing, low speed Boat cruises, Dam } \\
\text { High Activity Use Zone (Water) }\end{array}$ & $\begin{array}{l}\text { Speed Boat Racing, Canoe paddling/rowing races and competitions, Water sports, water } \\
\text { aerobics }\end{array}$ \\
\hline
\end{tabular}

(Source: GISPlan, BTO, 2017)

ity use zone (land and water) covers a total area of $2,295.83$ or $14.22 \%$ of the total DDLA. High tourism development use zone (land) covers a total area of $1,801.26$ or $11.15 \%$ of the total DDLA, while on the other hand, the low tourism development exclusive use zone (land and water) covers a total area of $1,133.83$ ha or $7.02 \%$ of the total DDLA. The smallest zones, under this proposal, in terms of size are low activity (water) and high activity (water) use zones occupies 143.10 ha and 86.10 ha respectively.

\section{Conclusion}

Sustainable planning and management of DDLA aimed to conserve and maintain the biodiversity of the area, as well as to support economic diversification of surrounding communities. In this respect, MCDA and numerous spatial analyses and evaluation of individual and group of parameters applied in this research are all regarded as an important tool for application of sustainability, smart growth, and green planning principles for tourism master planning in a protected area. The outcomes of the DDLA's spatial and suitability analysis has enabled a clearer understanding of the characteristics of the area as a spatial entity; a bio-physical environment; and its inherent development opportunities as a tourism destination.

MCDA based scenarios showed variations in the term of sustainability analysed through the three different scenario models: conservation, sustainable and intensive. Accordingly, and in the light of ecotourism and its key objectives, the most relevant scenario for further planning and management of land use zones was sustainable development. Zoning proposals of this scenario are good example of how should spatial planning be performed using modern techniques in the region where local communities are willing to at- tract investments for the development of ecotourism establishments.Therefore, a more "practical" policies and related strategies, that consists of specific problem-solving methods and management directions, should be developed in the future.

The flexibility in the use of MCDA and AHC techniques presents a promising new approach to improve interdisciplinary research as exemplified in this article. The analysis results give comfort in the rightful decision making by local and central government authorities, investors, developers and communities. The fact that every square meter is evaluated from different aspects confers the highest level of objectivity in making decision "where, how and when" to allocate planned developments within the perimeter of land zones with different suitability constraints and opportunities. In that regards the MCDA and AHC applied for the case of Dikgathlong Dam open a new chapter in Botswana tourism research and development planning practice. The intention of authors in further research is to apply similar methodology on different study areas in order to evaluate the performance of suggested concept as a basis for ecotourism development. 


\section{Acknowledgements}

We would like to express our gratitude to the consultants from GISPlan (Pty) Ltd. and Botswana Tourism Organization for sharing their valuable experience and critical input in applying the MCDA, AHC methodology for the first time in Botswana. Our extended gratitude also goes to the reviewers who helped to improve our paper with their constructive comments. This work has been supported in part by Croatian Science Foundation under the project UIP-2017-05-2694.

\section{References}

Abudeif, A. M., Moneim, A. A. \& Farrag, A. F. (2015). Multicriteria decision analysis based on analytic hierarchy process in GIS environment for siting nuclear power plant in Egypt, Annals of nuclear energy, 75(1), 682-692. doi: https://doi.org/10.1016/j. anucene.2014.09.024

Alexander, M. (2012). Decision-making using the analytic hierarchy process (AHP) and SAS/IML. The Proceedings of the Southeast SAS Users Group, Durham, NC, Available at: https://analytics.ncsu.edu/ sesug/2012/SD-04.pdf.

Al-Yahyai, S., Charabi, Y., Gastli, A., \& Al-Badi, A. (2012). Wind farm land suitability indexing using multi-criteria analysis. Renewable Energy, 44(1), 8087. doi:https://doi.org/10.1016/j.renene.2012.01.004

Ayalew, L., Yamagishi, H., \& Ugawa, N. (2004). Landslide susceptibility mapping using GIS-based weighted linear combination, the case in Tsugawa area of Agano River, Niigata Prefecture, Japan. Landslides, 1(1), 73-81. doi:10.1007/s10346-003ooo6-9

Basupi, B., Pansiri, J., \& Lenao, M. (2017). Botswana Tourism policy Landscape-successes and challenges. Botswana Journal of Business, 10(1), 83-96.

Blaszczynski, J.S. (1997). Landform characterization with geographic information systems. Photogrammetric Engineering \& Remote Sensing, 63(2), 183-191.

Bunruamkaew, K., \& Murayam, Y. (2011). Site suitability evaluation for ecotourism using GIS \& AHP: A case study of Surat Thani province, Thailand. Procedia-Social and Behavioral Sciences, 21(1), 269-278. doi:https://doi.org/10.1016/j.sbspro.2011.07.024

Çetinkaya, C., Kabak, M., Erbaş, M., \& Özceylan, E. (2018). Evaluation of ecotourism sites: a GIS-based multi-criteria decision analysis. Kybernetes, $47(8)$, 1664-1686. doi:https://doi. org/10.1108/K-10-2017-0392

Chandio, I.A., Matori, A.N., Yusof, K., Talpur, M.H., \& Aminu, M. (2014). GIS-basedland suitability analysis of sustainable hillside development. Procedia Engineering, 77(1), 87-94. doi:https://doi. org/10.1016/j.proeng.2014.07.009
Charabi, Y., \& Gastli, A. (2011). PV site suitability analysis using GIS-based spatial fuzzy multi-criteria evaluation. Renewable Energy, 33(9), 2554-2561. doi:https://doi.org/10.1016/j.renene.2010.10.037

Cobbinah, P.B. (2016). Contextualising the meaning of ecotourism. Tourism Management Perspectives, 16(1), 179-189. doi:https://doi.org/10.1016/j. tmp.2015.07.015

Curry, A.M., \& Horn, N. (2009). Dictionary of Geomrphology. Phnom Penn: Royal University of Phnom Penn, Department of Geography and Land Management.

Fang, Y. (2017). Site Selection of Ecotourism: A case study of Zhejiang Province. International Journal of Innovative Science, Engineering \& Technolo$g y, 4(3), 321-326$.

Fernández, D.S., \& Lutz, M.A. (2010). Urban flood hazard zoning in Tucumán Province, Argentina, using GIS and multicriteria decision analysis. Engineering Geology, 111(1), 90-98.

Gigović, L., Pamučar, D., Lukić, D., \& Marković, S. (2016). GIS-Fuzzy DEMATEL MCDA model for the evaluation of the sites for ecotourism development: A case study of "Dunavski ključ" region, Serbia. Land Use Policy, 58(1), 348-365. doi:https://doi. org/10.1016/j.landusepol.2016.07.03

GISPlan, BTO. (2016). The Development of Dikgathlong Dam Tourism Master Plan - Scoping Report. Revised Version 2.

GISPlan, BTO. (2017). Dikgathlong Dam Tourism Master Plan - Draft Master Plan. Revised Version 3. (str. 1-18).

Hengel, T. (2006). Finding the right pixel size. Computer and Geosciences, 32(9), 1283-1298.

Hoechstetter, S., Walz, U., Dang, L.H., \& Thinh, N.X. (2008). Effects of topography and surface roughness in analyses of landscape structure - a proposal to modify the existing set of landscape metrics. Landscape Online, 3(1), 1-14. doi:https://doi. org/10.3097/LO.200803

Hutchinson, M.F. (1989). A new procedure for gridding elevation and stream line data with automatic removal of spurious pits. Journal 
of Hydrology, 106(1), 211-232. doi:https://doi. org/10.1016/0022-1694(89)90073-5

Janke, J.R. (2010). Multicriteria GIS modeling of wind and solar farms in Colorado. Renewable Energy, 35(10), 2228-2234.

Jankowski, P., \& Richard, L. (1994). Integration of GIS-based suitability analysis and multicriteria evaluation in a spatial decision support system for route selection. Environment and Planning B: Planning and Design, 21(3), 323-340. doi:https://doi. org/10.1068/b210323

Jeong, J.S. (2016). A Spatial Regional Planning Assessment for Green Development Towards Ecotourism with Use of MCDA/SAW Method (Case Study: Spanish Rural Housings). Management, 1(4), 69-76. doi:https://doi.org/10.11648/j.urp.20160104.11

Kant Sharma, L., Kanga, S., Singh Nathawat, M., Sinha, S., \& Chandra Pandey, P. (2012). Fuzzy AHP for forest fire risk modeling. Disaster Prevention and Management: An International Journal, 21(2), 160171. doi:https://doi.org/10.1108/09653561211219964

Kaynak, E., \& Marandu, E.E. (2006). Tourism market potential analysis in Botswana: a Delphi study. Journal of Travel Research, 45(2), 227-237. doi:https://doi. org/10.1177/0047287506291595

Koschke, L., Fürst, C., Frank, S., \& Makeschin, F. (2012). A multi-criteria approach for an integrated land-cover-based assessment of ecosystem services provision to support landscape planning. Ecological Indicators, 21(1), 54-66. doi:https://doi. org/10.1016/j.ecolind.2011.12.010

Kumar, L., Skidmore, A.K., \& Knowles, E. (1997). Modelling topographic variation in solar radiation in a GIS environment. International Journal of Geographical Information Science, 11(5), 475-497. doi:https://doi.org/10.108o/136588197242266

Lee, S., \& Min, K. (2001). Statistical analysis of landslide susceptibility at Yongin, Korea. Environmental geology, 40(9), 1095-1113. doi:https://doi. org/10.1007/s002540100310

Lozić, S. (1995). Vertikalna raščlanjenost reljefa kopnenog dijela Republike Hrvatske. Acta Geographica Croatica, 30(1), 17-26.(in Croatian)

Mahdavi, A. \& Niknejad, M. (2014). Site suitability evaluation for ecotourism using MCDM methods and GIS: Case study - Lorestan province, Iran. Journal of Biodiversity and Environmental Sciences (JBES), (2014). 4(6), 425-437.

Malczewski, J. (2006). Ordered weighted averaging with fuzzy quantifiers: GIS-based multicriteria evaluation for land-use suitability analysis. International journal of applied earth observation and geoinformation, 8(4), 270-277. doi:https://doi. org/10.1016/j.jag.2006.01.003
Mardani, A., Jusoh, A., \& Zavadskas, E.K. (2015). Fuzzy multiple criteria decision-making techniques and applications - Two decades review from 1994 to 2014. Expert Systems with Applications, 42(8), 41264148. doi:https://doi.org/10.1016/j.eswa.2015.01.003

Mbaiwa, J.E. (2005). The problems and prospects of sustainable tourism development in the Okavango Delta, Botswana. Journal of Sustainable Tourism, 13(3), 203-227. doi:https://doi. org/10.1080/01434630508668554

Mendas, A., \& Delali, A. (2012). Integration of MultiCriteria Decision Analysis in GIS to develop land suitability for agriculture: Application to durum wheat cultivation in the region of Mleta in Algeria. Computers and Electronics in Agriculture, 83(1), 117-126. doi:https://doi.org/10.1016/j.compag.2012.02.003

Milevski, I. (2008). Estimation of soil erosion risk in the upper part of Bregalnica watershed-Republic of Macedonia, based on digital elevation model and satellite imagery. In: Proceedings from the 5 th international conference on geographic information systems. Istanbul: Fatih University, pp. 351-358.

Mitasova, H., Hofierka, J., Zlocha, M., \& Iverson, L.R. (1996). Modelling topographic potential for erosion and deposition using GIS. International Journal of Geographical Information Systems, 10(5), 629-641. doi:https://doi.org/10.1080/02693799608902101

Mohd, Z.H., \& Ujang, U. (2016). Integrating multiple criteria evaluation and GIS in ecotourism: a review. In: A. Abdul-Rahman et. al. (Eds), International Conference on Geomatic and Geospatial Technology (GGT), International Archives of the Photogrammetry, Remote Sensing \& Spatial Information Sciences, 42(35), 345-350, Malaysia: Kuala Lumpur.

Statistics Botswana. (2011). Population and Housing Census, Analytical Results. Gaborone.

Ryngnga, P.K. (2008). Ecotourism prioritization: a geographic information system approach. South Asian journal of tourism and heritage, 1(1), 49-56. doi:https://doi.org/10.1016/j.sbspro.2011.07.024

Saarinen, J., Hambira, W.L., Atlhopheng, J., \& Manwa, H. (2012). Tourism industry reaction to climate change in Kgalagadi South District, Botswana. Development Southern Africa, 29(2), 273-285. doi:https://doi.org/10.1080/0376835X.2012.675697

Saaty, T.L. (1990). How to make a decision: the analytic hierarchy process. European journal of operational research, 48(1), 9-26. doi:https://doi. org/10.1016/0377-2217(90)90057-I

Saaty, T.L. (2008). Decision making with the analytic hierarchy process. International journal of services sciences, 1(1), 83-98. doi:https://doi.org/10.1504/IJSSCI.2008.017590

Saha, A.K., Gupta, R.P., \& Arora, M.K. (2002). GISbased landslide hazard zonation in the Bhagirathi 
(Ganga) valley, Himalayas. International journal of remote sensing, 23(2), 357-369. doi:https://doi. org/10.1080/01431160010014260

Sappington, J.M., Longshore, K.M., \& Thompson, D.B. (2007). Quantifying landscape ruggedness for animal habitat analysis: a case study using bighorn sheep in the Mojave Desert. Journal of wildlife management, 71(5), 1419-1426. doi:https://doi. org/10.2193/2005-723

Schmidt, J., Evans, I.S., \& Brinkmann, J. (2003). Comparison of polynomial models for land surface curvature calculation. International Journal of $\mathrm{Ge}$ ographical Information Science, 17(8), 797-814. doi:https://doi.org/10.1080/1365881031000159605

Swanson, F.J., Kratz, T.K., Caine, N., \& Woodmansee, R.G. (1988). Landform effects on ecosystem patterns and processes. BioScience, 38(2), 92-98. doi:https://doi.org/10.2307/1310614

Šiljeg, A., Barada, M., \& Marić, I. (2018). Digital Terrain Modelling. University of Zadar - Alfa d.d., Zagreb.

Statistics Botswana. (2015). Tourism Statistics Annual Report 2013. Gaborone.

The International Ecotourism Society (TIES), (2015). Available at: http://www.ecotourism.org/what-isecotourism

Whelan, T. (1991). Ecotourism and its role in sustainable development. In: T. Whelan (Ed.), Nature tourism: Managing for the environment. (pp. 3-22). Washington, DC: Island Press.

Zhang, H.X., \& Yang, Q.S. (2009). Spatial distribution of rural tourism for construction new country based on MCDA. Human Geography, 19(3), 75-79. 